\title{
Profil Komposisi BTP Campuran, Pelabelan, dan Penggunaannya pada Industri Rumah Tangga Pangan (IRTP) di DKI Jakarta
}

\section{Composition Profile of Mixed Food Additives, Labeling, and Their Used by Home Food Industry in DKI Jakarta}

\begin{abstract}
Dewi Monita Sari ${ }^{1)}$, Nuri Andarwulan $\left.{ }^{1,2}\right)^{*}$, Dedi Fardiaz ${ }^{1,2)}$
${ }^{1)}$ Magister Profesional Teknologi Pangan, Institut Pertanian Bogor, Bogor

${ }^{1)}$ Departemen Ilmu dan Teknologi Pangan, Fakultas Teknologi Pertanian, Institut Pertanian Bogor, Bogor

${ }^{2)}$ South East Asian Food and Agricultural Science and Technology Center, Institut Pertanian Bogor, Bogor

Abstract. Mixed food additives had been registered at BPOM since 2012. However regulation concerning mixed food additives was issued in 2016 and applied in 2017. The compliance assessment regarding registered mixed food additives has not been conducted so far. This research was aimed to identify composition and the use of mixed food additives as declared on label, evaluate its compliance with regulation and its use by home food industries in Jakarta. The secondary data regarding the composition of mixed food additives were obtained from BPOM, while the primary data regarding the decralation of mixed food additives were obtained from the market in DKI Jakarta. The results showed that 78\% (494/632) registered mixed food additives were flavoring and colouring mixed food additive. The composition of mixed food additives divided into 3 part, namely the primary food additive which has a technological function in the final food product, the secondary food additive which has a technological function on mixed food additives and other ingredients that determine mixed food additives form (liquid, solid, powder, and paste/semisolid). The level of label sample complied with the regulation were 57\% (49/86). Regarding to survey result on 18 home food industry, 7 were founded to use 16 kinds of mixed food additives. The application of 4 among these 16 kinds of mixed food additives were exceeded based on maximum limit of the regulation that had been stated by BPOM.
\end{abstract}

Keywords: DKI Jakarta, home food industry, label, mixed food additive

Abstrak. BTP campuran terdaftar di BPOM sejak tahun 2012. Namun peraturan yang khusus mengatur BTP campuran diterbitkan tahun 2016 dan diberlakukan tahun 2017. Selama ini belum ada penelitian tentang BTP campuran yang terdaftar tersebut. Tujuan dari penelitian ini adalah mengidentifikasi komposisi dan label edar BTP campuran, mengevaluasi kesesuaiannya dengan peraturan dan penggunaannya oleh IRTP. Data yang digunakan berupa data sekunder yaitu komposisi dari BTP campuran yang diperoleh dari BPOM dan data primer yaitu label edar BTP campuran yang diperoleh dari supermarket dan toko bahan kue di DKI Jakarta. Hasil penelitian menunjukan bahwa BTP campuran terdaftar didominasi oleh BTP campuran perisa dan pewarna 78\% (494/632). Komposisi dari BTP campuran dibagi menjadi tiga yaitu BTP utama yang mempunyai fungsi teknologi pada produk pangan akhir, BTP sekunder yang mempunyai fungsi teknologi pada sediaan BTP campuran dan bahan lain yang mempengaruhi bentuk sediaan dari BTP campuran (cair, padat, bubuk, dan pasta/semisolid). Tingkat pemenuhan sampel label edar yang sesuai dengan peraturan adalah sebesar 57\% (49/86). Berdasarkan hasil survei terhadap 18 IRTP, terdapat 7 IRTP yang menggunakan BTP campuran dengan BTP campuran yang digunakan sebanyak 16 jenis, dari 16 jenis tersebut terdapat 4 BTP campuran yang digunakan melebihi batas maksimum penggunaan yang ditetapkan oleh BPOM.

Kata Kunci: BTP campuran, DKI Jakarta, IRTP, label

Aplikasi Praktis: Penelitian ini memberikan informasi kepada regulator tentang profil BTP campuran, kesesuaian label edar dengan peraturan dan keamanan penggunaan BTP campuran oleh industri rumah tangga pangan. Hasil penelitian dapat digunakan sebagai rujukan dan pertimbangan dalam implementasi peraturan BTP campuran.

\section{PENDAHULUAN}

Regulatory Impact Assessment (RIA) adalah sebuah metode untuk mengevaluasi kebijakan yang bertujuan menilai secara sistematis pengaruh positif dan negatif

Korespondensi: nuriandarwulan@yahoo.com suatu regulasi yang sedang diusulkan atau yang sedang berjalan (Nasokah 2008). Peraturan bahan tambahan pangan (BTP) Campuran diterbitkan tahun 2016 dan baru diberlakukan 2017 akhir. Sediaan BTP campuran terdaftar di BPOM melalui mekanisme ijin khusus dari tahun 2012, kajian terhadap BTP campuran yang telah terdaftar dapat dijadikan dasar penentuan pengaruh 
positif dan negatif penerapan peraturan BTP campuran. BTP campuran adalah BTP yang mengandung dua atau lebih jenis BTP dari golongan BTP yang sama atau pun berbeda dengan atau tanpa penambahan bahan lain yang diizinkan (BPOM 2016a). BTP campuran yang terdaftar di BPOM (2012-2017) sebanyak 632 produk.

Di Indonesia BTP campuran merupakan campuran dua atau lebih BTP dan tidak diatur secara spesifik BTP yang boleh ditambahkan pada BTP lainnya. Hasil sidang Codex Committee on Food Additive (CCFA) ke 47 tahun 2015, definisi BTP sekunder (secondary food additive) yaitu BTP yang ditambahkan dalam preparasi atau proses pembuatan BTP, enzim, dan perisa. BTP sekunder mempunyai fungsi teknologi seperti pengawet, pendispersi, dan pelarut bahan tambahan pangan, enzim, dan perisa namun tidak mempunyai fungsi teknologi pada produk pangan akhir. Bahan penolong proses tidak termasuk BTP sekunder. Eropa mengatur penggunaan BTP dan pembawa BTP sekunder karena mempunyai fungsi teknologi (European Commission 2011).

BTP campuran yang beredar di pasar kebanyakan dalam kemasan kecil 25, 30, atau $60 \mathrm{~mL}$ sediaan bentuk pasta dan ukuran berat 30 dan $60 \mathrm{~g}$ sediaan bentuk padat. BTP campuran pada umumnya digunakan oleh rumah tangga dan industri rumah tangga pangan. Belum ada penelitian khusus tentang profil sediaan BTP campuran yang telah terdaftar dari segi komposisi, nama jenis, kesesuaian pelabelan maupun penggunaannya oleh pelaku usaha IRTP. Oleh karena itu tujuan penelitian ini adalah mengidentifikasi komposisi sediaan BTP campuran terdaftar, pemetaan kelas fungsi BTP campuran terdaftar, mengevaluasi kesesuaian label edar BTP campuran dengan peraturan, dan mengevaluasi keamanan penggunaan sediaan BTP campuran oleh IRTP. Label sediaan BTP campuran merupakan hal yang penting untuk diperhatikan, karena terdapat informasi produk sehingga konsumen dapat menentukan pilihan sebelum membeli. Pengunaan sediaan BTP campuran oleh pelaku usaha IRTP perlu dievaluasi terkait keamanan pangannya, sebab penggunaan BTP yang berlebihan adalah salah satu masalah keamanan pangan yang banyak ditemukan (Rahayu 2011).

\section{BAHAN DAN METODE}

\section{Bahan}

Bahan yang digunakan adalah data BTP campuran yang terdaftar di BPOM tahun 2012-2017, label BTP campuran dari produk supermarket atau toko bahan kue di DKI Jakarta, data jumlah IRTP tahun 2017 yang terdaftar di Dinas Penanaman Modal dan Pelayanan Terpadu Satu Pintu DKI Jakarta. Pengolahan data menggunakan Microsoft Excel 2016.

\section{Metode}

Penelitian dibagi empat tahap, (1) Pengumpulan data BTP campuran; (2) Identifikasi komposisi BTP campuran; (3) Evaluasi kesesuaian label edar BTP campuran dengan peraturan; (4) Evaluasi penggunaan BTP campuran oleh industri rumah tangga pangan.

\section{Pengumpulan data BTP campuran}

Data BTP campuran yang terdaftar di BPOM tahun 2012-2017 dari e-tracking BPOM, data komposisi, dan batas maksimum penggunaan diolah secara diskriptif.

\section{Identifikasi komposisi BTP campuran}

Komposisi BTP campuran dikelompokkan ke dalam tiga kelompok berdasarkan nama jenisnya, yaitu BTP utama yang mempunyai fungsi teknologi pada produk pangan akhir. Menurut BPOM (2016a) BTP campuran wajib mencantumkan nama golongan BTP yang mempunyai fungsi utama, BTP sekunder yaitu BTP yang ditambahkan dalam preparasi pembuatan bahan tambahan pangan (European Commission 2011).

\section{Evaluasi kesesuaian antara peraturan dengan label edar BTP campuran}

Evaluasi melalui survei produk yang beredar di DKI Jakarta dengan sampel random berstrata (Nasution 2003). Jumlah sampel ditentukan dengan rumus Slovin menggunakan presisi 10\% tingkat kepercayaan 90\% (Sevilla 2007). Dilakukan evaluasi kesesuaian label edar dengan peraturan PerKa BPOM No. 27 Tahun 2017 tentang pendaftaran pangan olahan dan PerKa BPOM No. 8 Tahun 2016 tentang persyaratan BTP campuran. Bentuk fisik BTP campuran diteliti secara visual.

\section{Evaluasi penggunaan BTP campuran oleh industri rumah tangga pangan (IRTP)}

Evaluasi dilaksanakan melalui tahap pengumpulan data IRTP yang terdaftar di DKI Jakarta, pengelompokkan IRTP yang diduga menggunakan BTP campuran, penentuan jumlah IRTP yang disurvei menggunakan rumus Slovin dengan presisi 10\%, tingkat kepercayaan 90\% (Sevilla 2007). Penentuan IRTP yang disurvei mengunakan simple random sampling. Penyusunan kuisioner data nama dan alamat IRTP, jenis produk yang diproduksi, jenis produk yang menggunakan BTP campuran, jenis BTP campuran yang digunakan serta kadar BTP campuran yang digunakan. Selanjutnya evaluasi kesesuaian penggunaan BTP campuran yang digunakan IRTP secara perhitungan dengan peraturan.

\section{HASIL DAN PEMBAHASAN}

\section{Jenis BTP campuran terdaftar di BPOM}

BTP campuran yang terdaftar di BPOM tahun 20122017 sebanyak 632 produk, terdiri dari BTP campuran perisa dan pewarna $78 \%$ berdasarkan deskripsi umum di industri perisa (Sjahwil et al. 2014), kategori sweet terdiri atas kelompok spicy woody, herbal, floral, fantasi, kacang-kacangan, dairy, sweet brown, buah-buahan, berry, citrus, kategori savory kelompok sayuran; BTP campuran pewarna $17 \%$ berdasarkan warna dasar, yaitu kuning, merah, coklat, hijau, ungu, oranye, hitam, biru; BTP campuran pengemulsi 2\%; BTP campuran pengembang $1 \%$; BTP campuran penguat rasa $1 \%$; dan BTP campuran sirup 1\% (Gambar 1). 


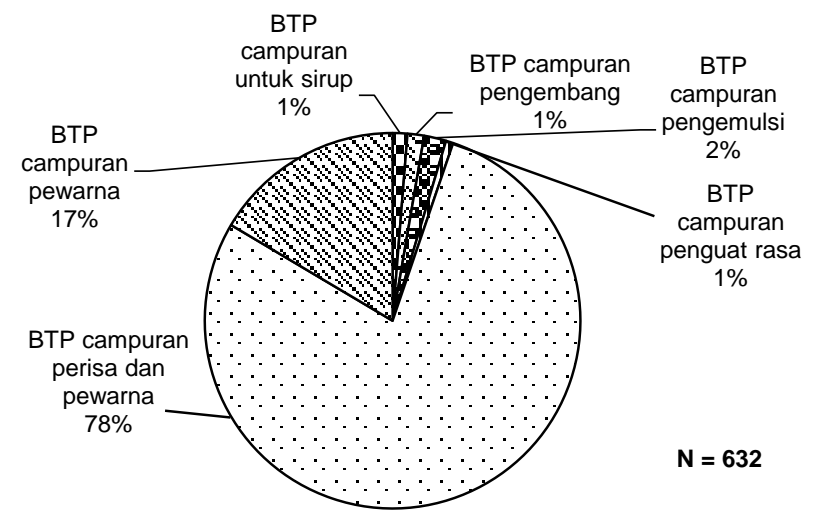

Gambar 1. Profil BTP campuran terdaftar di BPOM (20122017) hasil dari e-tracking

\section{Profil komposisi BTP campuran}

\section{BTP utama (primary food additive)}

BTP utama mempunyai fungsi teknologi pada produk pangan akhir. Menurut BPOM (2016a) BTP campuran wajib mencantumkan nama golongan BTP yang mempunyai fungsi utama pada nama jenisnya. BTP campuran untuk sirup tidak dibedakan antara BTP utama dan sekunder karena tidak disebutkan secara spesifik BTP yang mempunyai fungsi utama (Tabel 1).

BTP utama pada BTP campuran perisa dan pewarna adalah perisa dan pewarna. Etil maltol dan etil vanilin digunakan di kelompok 98\% (483/493) kategori sweet, kecuali kelompok dairy dan kacang-kacangan. Etil maltol adalah perisa pada produk dengan cita rasa manis (sweet), karakteristik etil maltol ini berbau karamel atau buah masak (Zhu dan Xiao 2015). Etil vanilin adalah senyawa sintetik dari sintesis eugonel dalam minyak cengkeh yang banyak digunakan sebagai perisa dalam minuman dan makanan (Kumar et al. 2012). Limonene hanya digunakan kelompok citrus, memberikan kontribusi besar pada keseluruhan aroma lemon-lime pada minuman berkarbonasi (Hausch et al. 2014). Linalool dan benzaldehyde merupakan komponen volatile dalam teh hijau (Lee et al. 2013), hanya terdapat pada kelompok herbal, terdiri atas BTP campuran perisa teh dan pewarna dan BTP campuran perisa teh hijau dan pewarna. Furfuryl mercaptan adalah komponen perisa kopi (Blank et al. 2002), digunakan hanya pada kelompok sweet brown, terdiri dari BTP campuran perisa kopi dan pewarnai. Karmoisin, tartarzin, biru berlian, ponceau, dan kuning FCF adalah pewarna digunakan di hampir semua BTP campuran perisa dan pewarna.

\section{BTP sekunder (secondary food additive)}

Batas maksimum menurut European Commission (2011) tentang penggunaan BTP sekunder dalam BTP, enzim, perisa, dan zat gizi serta BPOM (2016b) tentang ajudan perisa dalam perisa dijadikan acuan menentukan batas maksimum penggunaan BTP sekunder. Batas maksimum berarti jumlah BTP sekunder mempunyai fungsi teknologi dalam BTP campuran, namun tidak mempunyai fungsi teknologi pada produk pangan akhir.
Batas maksimum tidak berhubungan dengan aspek keamanan penggunaan BTP campuran. BTP sekunder dengan batas CPPB berfungsi sebagai bahan pembawa untuk memfasilitasi penanganan, aplikasi, penggunaan BTP lain di dalam pangan dengan cara melarutkan, mengencerkan, mendispersikan atau memodifikasi secara fisik BTP lain tanpa mengubah fungsinya dan tidak mempunyai efek teknologi pada pangan (BPOM 2013).

BTP sekunder pada BTP campuran perisa dan pewarna disajikan pada Tabel 2. Sebanyak 139 dari 489 menambahkan natrium benzoat melebihi batas maksimum dalam European Commission (2011) dan BPOM (2016b). BTP sekunder dalam BTP campuran pewarna (Tabel 3) tidak ada yang melebihi batas dalam European Commission (2011). BTP sekunder pada BTP campuran pengembang (Tabel 4) terdapat penambahan penstabil BTP bentuk bubuk untuk menstabilkan sistem dispersi homogen pada pangan (BPOM 2013).

Penambahan penstabil untuk mempertahankan agar partikel padatan tetap terdispersi secara merata ke seluruh bagian medium pendispersi dan tidak terjadi penggabungan partikel padatan yang ada, sehingga penstabil yang ditambahkan tersebut tidak mempunyai fungsi teknologi pada BTP campuran pengembang yang berbentuk bubuk (Dewayani et al. 2002). Penstabil ini berfungsi sebagai BTP utama yang mempunyai fungsi teknologi pada produk pangan akhir. Pada BTP campuran pengembang dan pengemulsi penambahan perlakuan tepung dan antioksidan kemungkinan berpengaruh pada produk pangan akhir. BTP sekunder pada BTP campuran pengemulsi (Tabel 5) terdapat pewarna tartrazin dan kuning FCF sedangkan menurut European Commission (2011) BTP selain bahan pembawa (carier) yang ditambahkan kedalam sediaan BTP tidak boleh berfungsi sebagai pewarna, pemanis atau penguat rasa.

\section{Zat tambahan lainnya dalam BTP campuran}

Zat tambahan lain berhubungan dengan bentuk sediaan dari BTP campuran. Zat tambahan lain pada BTP campuran perisa dan pewarna bentuk pasta adalah glukosa, sukrosa, maltose, fruktosa, air, minyak nabati, dan cloudifier, pada sediaan bubuk zat lain yang ditambahkan adalah $\mathrm{NaCl}$, pati jagung, laktosa, dan dekstrosa monohidrat, pada sediaan cair yang ditambahkan adalah air, etanol, dan propanol. Zat tambahan lainnya yang ditambahkan BTP campuran pewarna bentuk bubuk adalah $\mathrm{NaCl}$ dan maltodekstrin, pada sediaan pasta yang ditambahkan adalah air, glukosa, lemak nabati, sirup fruktosa, dan sukrosa pada bentuk sediaan cair yang ditambahkan adalah air.

BTP campuran pengembang bentuk fisik seluruhnya adalah bubuk dan zat tambahan lainnya yang ditambahkan pada BTP campuran pengembang ini adalah pati jagung, $\mathrm{NaCl}$ dan tepung tapioka. Zat tambahan lainnya yang ditambahkan pada BTP campuran pengemulsi bentuk padat adalah air, palm stearin, dan minyak nabati, sedangkan pada bentuk sediaan bubuk yang ditambahkan adalah pati tapioka. 
Bentuk fisik BTP campuran (Gambar 2) didominasi bentuk pasta, yaitu bentuk semi solid atau cairan yang sangat kental. Sediaan BTP campuran perisa dan pewarna bentuk fisiknya didominasi oleh bentuk pasta ini, selain pasta banyak juga yang berbentuk cair atau dikenal dengan istilah essen, pada essen ini selain perisa dan pewarna bahan yang ditambahkan adalah air, propilen glikol atau alkohol sehingga bentuknya sangat cair menyerupai air. BTP campuran pewarna, pengembang, dan penguat rasa bentuk fisik didominasi oleh bentuk bubuk. BTP campuran pengemulsi bentuk fisiknya cenderung padat.

Tabel 1. BTP utama pada BTP campuran

\begin{tabular}{|c|c|c|c|}
\hline \multicolumn{2}{|c|}{ BTP Campuran } & \multicolumn{2}{|r|}{ BTP Utama } \\
\hline Jenis & Kelompok & Golongan BTP & Jenis BTP \\
\hline \multirow[t]{22}{*}{$\begin{array}{l}\text { Perisa dan } \\
\text { pewarna }\end{array}$} & \multirow[t]{2}{*}{ Citrus } & Perisa & $\begin{array}{l}\text { perisa jeruk manis, jeruk keprok, lemon, jeruk, etil vanilin, cis-3-hexeral, etil butirat, minyak lemon, } \\
\text { minyak jeruk, limonene, etil maltol }\end{array}$ \\
\hline & & Pewarna & Karmoisin, tartrazin, biru berlian, ponceau, kuning fcf, merah allura \\
\hline & \multirow[t]{2}{*}{ Berry } & Perisa & $\begin{array}{l}\text { perisa frambozen, stroberi, rum, santa merah, blueberry, anggur, cranberry, etil vanilin, vanilin, cis- } \\
\text { 3-hexeral, isoamil butirat, isoamil asetat, etil asetat, etil butirat, metil antranilat, metil cinnamate, etil } \\
\text { maltol }\end{array}$ \\
\hline & & Pewarna & karmoisin, tartrazin, biru berlian, eritrosin, ponceau, kuning fcf, merah allura \\
\hline & Buah-buahan & Perisa & $\begin{array}{l}\text { perisa nanas, pisang ambon, pisang, nangka, markisa, melon, durian, sirsak, mangga, asem jawa, } \\
\text { alpukat, blewah, susu, jambu, apel, isoamil asetat, etil asetat, isoamil butirat, etil butirat, allyl } \\
\text { caproat, etil vanilin, etil maltol }\end{array}$ \\
\hline & \multirow[t]{2}{*}{ Sweet brown } & $\begin{array}{l}\text { Pewarna } \\
\text { Perisa }\end{array}$ & $\begin{array}{l}\text { Karmoisin, tartrazin, biru berlian, ponceau, karamel IV, kuning fcf } \\
\text { perisa moka, moka hopjes, coklat blackforest, coklat, dark coklat, kopi moka, kopi, butter, susu, } \\
\text { tiramisu, karamel, etil vanilin, cis-3-hexeral, diacetil, furfuryl mercaptan, etil maltol }\end{array}$ \\
\hline & & Pewarna & $\begin{array}{l}\text { karmoisin, tartrazin, biru berlian, ponceau, coklat ht, karamel I, karamel III, karamel IV, kuning fcf, } \\
\text { merah allura, indigotin }\end{array}$ \\
\hline & \multirow[t]{2}{*}{ Dairy } & Perisa & perisa butter, minyak keju butter, minyak keju, susu, vanilla mentega \\
\hline & & Pewarna & karmoisin, tartarzin, ponceau, karamel III, kuning fcf \\
\hline & Kacang- & Perisa & perisa almong dan kacang hijau \\
\hline & kacangan & Pewarna & tartarzin, biru berlian, coklat ht \\
\hline & Fantasi & $\begin{array}{l}\text { Perisa } \\
\text { Pewarna }\end{array}$ & $\begin{array}{l}\text { perisa susu, pandan, doger, tutti fruiti, sarsaparilla, es teler, isoamil asetat, etil vanilin, etil maltol } \\
\text { karmoisin, tartarzin, biru berlian, eritrosin, ponceau, karamel IV, kuning fcf }\end{array}$ \\
\hline & \multirow[t]{2}{*}{ Floral } & Perisa & perisa rose, etil vanilin, etil maltol \\
\hline & & Pewarna & karmoisin, tartrazin, eritrosin, ponceau, kuning fcf \\
\hline & \multirow[t]{2}{*}{ Herbal } & Perisa & perisa teh, teh hijau, etil vanilin, linalool, benzaldehid, etil maltol \\
\hline & & Pewarna & karmoisin, tartrazin, biru berlian, coklat ht, karamel IV, kuning fcf \\
\hline & \multirow[t]{2}{*}{ Spicy woody } & Perisa & $\begin{array}{l}\text { perisa pandan, cocopandan, kelapa, iso amil asetat, etil vanilin, vanilin, perisa kelapa, minyak pala, } \\
\text { etil maltol }\end{array}$ \\
\hline & & Pewarna & karmoisin, tartarzin, biru berlian, ponceau, coklat ht, karamel III, karamel IV, kuning fcf, indigotin \\
\hline & \multirow{2}{*}{ Lain-lain } & Perisa & perisa rum, brandy, taro, etil vanilin, vanilin, etil maltol \\
\hline & & Pewarna & karmoisin, tartarzin, biru berlian, eritrosin, ponceau, coklat ht, karamel IV, merah allura \\
\hline & \multirow[t]{2}{*}{ Sayuran } & Perisa & perisa tomat \\
\hline & & Pewarna & ponceau, kuning fcf \\
\hline \multirow[t]{9}{*}{ Pewarna } & Coklat & Pewarna & coklat ht, biru berlian, tartrazin, kuning fcf, ponceau, karmoisin, indigotin, eritrosin, merah allura \\
\hline & Hijau & Pewarna & biru berlian, tartrazin, indigotin, merah allura \\
\hline & Merah & Pewarna & biru berlian, tartrazin, kuning fcf, ponceau, karmoisin, indigotin, eritrosin, merah allura \\
\hline & Kuning & Pewarna & biru berlian, tartrazin, kuning fcf, ponceau, merah allura \\
\hline & Oranye & Pewarna & tartarzin, kuning fcf, ponceau, karmoisin \\
\hline & Ungu & Pewarna & biru berlian, karmoisin, eritrosin, merah allura \\
\hline & Hitam & Pewarna & coklat ht, biru berlian, tartarzin, kuning fcf, ponceau, karmoisin, indigotin, merah alllura \\
\hline & Biru & Pewarna & biru berlian, tartrazin, karmoisin, indigotin, eritrosin, merah allura \\
\hline & Lain-lain & Pewarna & biru berlian, tartrazin, kuning fcf, eritrosin, merah allura \\
\hline \multirow[t]{7}{*}{ Pengembang } & Pengembang & Pengembang & natrium hidrogen karbonat, kalsium karbonat \\
\hline & Pengembang & Pengembang & natrium karbonat, natrium bikarbonat \\
\hline & dan penstabil & Penstabil & natrium tripolifosfat, kalsium karbonat, dinatrium difosfat, trikalsium fosfat \\
\hline & Pengembang & Pengembang & kalsium karbonat \\
\hline & dan pengemulsi & Pengemulsi & mono dan digliserida asam lemak, ester poligliserol asam lemak, natrium stearoil - 2 - laktilat \\
\hline & Pengembang & Pengembang & kalsium karbonat, natrium bikarbonat \\
\hline & dan pengawet & Pengawet & kalsium propionat \\
\hline \multirow[t]{3}{*}{ Pengemulsi } & Pengemulsi & Pengemulsi & $\begin{array}{l}\text { mono dan diester asam lemak, ester poligliserol asam lemak, ester asam lemak dan asetat dari } \\
\text { gliserol, ester propilen glikol asam lemak, lesitin kedelai }\end{array}$ \\
\hline & $\begin{array}{l}\text { Pengemulsi dan } \\
\text { perlakuan } \\
\text { tepung }\end{array}$ & $\begin{array}{l}\text { Pengemulsi } \\
\text { Perlakuan } \\
\text { tepung }\end{array}$ & $\begin{array}{l}\text { monogliserida, ester asam lemak dan diasetiltartrat dari gliserol } \\
\text { enzim amilase }\end{array}$ \\
\hline & $\begin{array}{l}\text { Pengemulsi dan } \\
\text { pewarna }\end{array}$ & $\begin{array}{l}\text { Pengemulsi } \\
\text { Pewarna }\end{array}$ & $\begin{array}{l}\text { monogliserida, poligliserol ester, polisorbat } \\
\text { tartrazin, kuning fcf, coklat ht }\end{array}$ \\
\hline \multirow[t]{4}{*}{ Untuk sirup } & \multirow[t]{4}{*}{ Untuk sirup } & $\begin{array}{l}\text { Pengatur } \\
\text { keasaman }\end{array}$ & asam sitrat \\
\hline & & Pemanis & natrium siklamat, sorbitol \\
\hline & & Pewarna & karmoisin, tartrazin, biru berlian \\
\hline & & Perisa & perisa frambozen, cocopandan, nanas, melon, jeruk, leci, rose \\
\hline Penguat rasa & Penguat rasa & Penguat rasa & mononatrium glutamat, dinatrium inosinat, dinatrium guanilat, dinatrium ribonukleotida \\
\hline
\end{tabular}


Tabel 2. BTP sekunder pada BTP campuran perisa dan pewarna

\begin{tabular}{|c|c|c|c|c|c|c|c|c|c|c|c|}
\hline BTP Sekunder & $\begin{array}{l}\text { Citrus } \\
(\mathrm{N}=56)\end{array}$ & $\begin{array}{c}\text { Berry } \\
(\mathrm{N}=82)\end{array}$ & $\begin{array}{c}\text { Buah- } \\
\text { buahan } \\
(\mathrm{N}=160)\end{array}$ & $\begin{array}{l}\text { Sweet } \\
\text { brown } \\
(\mathrm{N}=80)\end{array}$ & $\begin{array}{l}\text { Dairy } \\
(\mathrm{N}=8)\end{array}$ & $\begin{array}{c}\text { Kacang- } \\
\text { kacangan } \\
(\mathrm{N}=2)\end{array}$ & $\begin{array}{c}\text { Fantasi } \\
(\mathrm{N}=16)\end{array}$ & $\begin{array}{l}\text { Floral } \\
(\mathrm{N}=4)\end{array}$ & $\begin{array}{l}\text { Herbal } \\
(\mathrm{N}=10)\end{array}$ & $\begin{array}{c}\text { Spicy } \\
\text { wood } \\
(\mathrm{N}=61)\end{array}$ & $\begin{array}{c}\text { Lain- } \\
\text { lain } \\
(\mathrm{N}=14) \\
\end{array}$ \\
\hline & $\mathbf{N}^{\star}$ & $\mathbf{N}^{\star}$ & $\mathbf{N}^{*}$ & $\mathrm{~N}^{*}$ & $\mathbf{N}^{\star}$ & $\mathbf{N}^{\star}$ & $\mathbf{N}^{\star}$ & $\mathbf{N}^{\star}$ & $\mathbf{N}^{*}$ & $\mathbf{N}^{*}$ & $\mathbf{N}^{*}$ \\
\hline \multicolumn{12}{|l|}{ Pengemulsi } \\
\hline Gum xanthan & 4 & 17 & 14 & 5 & 1 & & 4 & & & 8 & 2 \\
\hline Gum arabic & 14 & 12 & 47 & 2 & & & 7 & & 2 & 10 & \\
\hline Gum rosin & 4 & 2 & 18 & & & & 3 & & & 3 & \\
\hline Gum tragacanth & 1 & 1 & & & & & & & & & \\
\hline Gum guar & & 8 & 9 & & & & 2 & & & 2 & \\
\hline Lesitin kedelai & & & & & 1 & & & & & & \\
\hline \multicolumn{12}{|l|}{ Pengawet } \\
\hline Natrium benzoat & 20 & 30 & 75 & 28 & 1 & 1 & 9 & & 2 & 24 & 1 \\
\hline Kalium sorbat & 2 & 3 & & 9 & 4 & & 1 & & 2 & 8 & \\
\hline Metil para hidroksibenzoat & 3 & 4 & 4 & & & & & & & & \\
\hline Natrium propionat & 2 & & & & & & & & & 2 & \\
\hline \multicolumn{12}{|l|}{ Pembawa } \\
\hline Propilen glikol & 12 & 27 & 44 & 24 & 1 & 1 & 3 & 2 & 4 & 18 & 7 \\
\hline Asam sitrat & 11 & 14 & 37 & 6 & 1 & & 2 & 1 & 1 & 9 & 1 \\
\hline Asam asetat & 1 & & & & & & & & & & \\
\hline \multicolumn{5}{|l|}{ Penstabil } & & & 1 & & & & \\
\hline $\begin{array}{l}\text { Natrium karboksimetil } \\
\text { selulosa }\end{array}$ & 1 & & 1 & 3 & & & & & 1 & 3 & 1 \\
\hline \multicolumn{12}{|l|}{ Pemanis } \\
\hline \multicolumn{12}{|l|}{ Antioksidan } \\
\hline $\mathrm{BHT}$ & 4 & 4 & 12 & & & 1 & 7 & & & 1 & \\
\hline $\mathrm{BHA}$ & 1 & & & & & & & & & & \\
\hline \multicolumn{12}{|l|}{ Humektan } \\
\hline Gliserin & & 1 & 2 & & & & & & & 2 & \\
\hline
\end{tabular}

Tabel 3. BTP sekunder pada BTP campuran pewarna

\begin{tabular}{|c|c|c|c|c|c|c|c|c|c|c|c|}
\hline \multirow[b]{2}{*}{$\begin{array}{c}\text { BTP } \\
\text { Sekunder }\end{array}$} & \multicolumn{9}{|c|}{ Bahan Tambahan Pangan Campuran Pewarna (Rata-Rata dalam g/kg) } & \multirow{2}{*}{$\begin{array}{c}\text { Batas Maksimum } \\
\text { Bahan Pembawa } \\
\text { (Carier) dalam } \\
\text { BTP }(\mathbf{g} / \mathbf{k g})^{\star}\end{array}$} & \multirow{2}{*}{$\begin{array}{l}\text { Batas Maksimum } \\
\text { BTP Selain Bahan } \\
\text { Pembawa (Carier) } \\
\text { dalam BTP }(\mathrm{g} / \mathrm{kg})^{\star}\end{array}$} \\
\hline & $\begin{array}{c}\text { Coklat } \\
\mathrm{N}=14\end{array}$ & $\begin{array}{l}\text { Hijau } \\
N=15\end{array}$ & $\begin{array}{c}\text { Merah } \\
\mathrm{N}=24\end{array}$ & $\begin{array}{c}\text { Kuning } \\
\mathrm{N}=26\end{array}$ & $\begin{array}{c}\text { Oranye } \\
\mathrm{N}=5\end{array}$ & $\begin{array}{c}\text { Ungu } \\
\mathrm{N}=7\end{array}$ & $\begin{array}{c}\text { Hitam } \\
\mathrm{N}=7\end{array}$ & $\begin{array}{l}\text { Biru } \\
\mathrm{N}=2\end{array}$ & $\begin{array}{l}\begin{array}{l}\text { Lain- } \\
\text { lain }\end{array} \\
\mathrm{N}=4\end{array}$ & & \\
\hline \multicolumn{12}{|l|}{ Pemanis } \\
\hline Sorbitol & 921 & 912 & 979 & 805 & 656 & 385 & & & & CPPB & \\
\hline \multicolumn{12}{|c|}{ Pengatur Keasaman } \\
\hline Natrium sulfat & 410 & 809 & 720 & 797 & 730 & 657 & 756 & & & CPPB & \\
\hline $\begin{array}{l}\text { Asam sitrat } \\
\text { Pembawa }\end{array}$ & 1 & 1 & 2 & 1 & & 1 & 1 & 1 & 1 & & \\
\hline Propilen glikol & & 150 & & 150 & 100 & 122 & & 150 & & $\begin{array}{l}1 \text { pada produk } \\
\text { pangan akhir } \\
\text { (sebagai carry } \\
\text { over) }\end{array}$ & \\
\hline Pengawet & & & & & & & & & & & \\
\hline $\begin{array}{l}\text { Natrium } \\
\text { benzoat }\end{array}$ & 1 & 1 & 1 & 1 & & 1 & 1 & 1 & 1 & & $\begin{array}{l}1.5 \text { tunggal atau } \\
\text { kombinasi dengan } \\
\text { sorbat, asam } \\
\text { benzoat dan kalium } \\
\text { benzoat }\end{array}$ \\
\hline Kalium sorbat & 1 & 1 & 1 & 1 & & 1 & 1 & 1 & 1 & & $\begin{array}{l}1.5 \text { tunggal atau } \\
\text { kombinasi dengan } \\
\text { natrium benzoat, } \\
\text { asam benzoat }\end{array}$ \\
\hline $\begin{array}{l}\text { Pengemulsi } \\
\text { Lesitin kedelai }\end{array}$ & & & 7 & & & & & & & CPPB & \\
\hline Pati modifikasi & 31 & 29 & 46 & 34 & & 24 & 47 & 45 & 31 & & \\
\hline $\begin{array}{l}\text { Gom } \\
\text { karagenan }\end{array}$ & 1 & 1 & 2 & 1 & & 1 & 1 & 1 & 1 & CPPB & \\
\hline $\begin{array}{l}\text { Gom xantan } \\
\text { Humektan }\end{array}$ & 1 & 1 & 2 & 1 & & 1 & 1 & 1 & 1 & CPPB & \\
\hline Gliserin & 145 & 170 & 170 & 170 & & 152 & 120 & 170 & 165 & & \\
\hline
\end{tabular}

Tabel 4. BTP sekunder pada BTP campuran pengembang

\begin{tabular}{|c|c|c|c|c|}
\hline \multirow[t]{2}{*}{ BTP Sekunder } & $\begin{array}{l}\text { BTP.C Pengembang } \\
\text { (Rata-Rata dalam g/kg) }\end{array}$ & $\begin{array}{c}\text { BTP.C Pengembang dan } \\
\text { Penstabil } \\
\text { (Rata-Rata dalam g/kg) }\end{array}$ & $\begin{array}{c}\text { BTP.C Pengembang dan } \\
\text { Pengemulsi } \\
\text { (Rata-Rata dalam g/kg) }\end{array}$ & \multirow[t]{2}{*}{$\begin{array}{c}\text { Batas Maksimum Bahan } \\
\text { Pembawa (Carier) dalam } \\
\text { BTP }(\mathrm{g} / \mathrm{kg})^{\star}\end{array}$} \\
\hline & $\mathrm{N}=2$ & $\mathrm{~N}=2$ & $\mathrm{~N}=2$ & \\
\hline \multicolumn{5}{|l|}{ Penstabil } \\
\hline Monokalsium fosfat & 55 & & & CPPB \\
\hline Dikalsium difosfat & 65 & & & CPPB \\
\hline \multicolumn{5}{|l|}{ Antikempal } \\
\hline Silicon dioksida & 0.3 & & & CPPB \\
\hline Kalsium karbonat & 165 & & & CPPB \\
\hline \multicolumn{5}{|l|}{ Pengatur Keasaman } \\
\hline Asam sitrat & & 10 & & CPPB \\
\hline \multicolumn{5}{|l|}{ Perlakuan tepung } \\
\hline Amilase & & & 20 & \\
\hline \multicolumn{5}{|l|}{ Antioksidan } \\
\hline Asam askorbat & & & 0.2 & \\
\hline
\end{tabular}




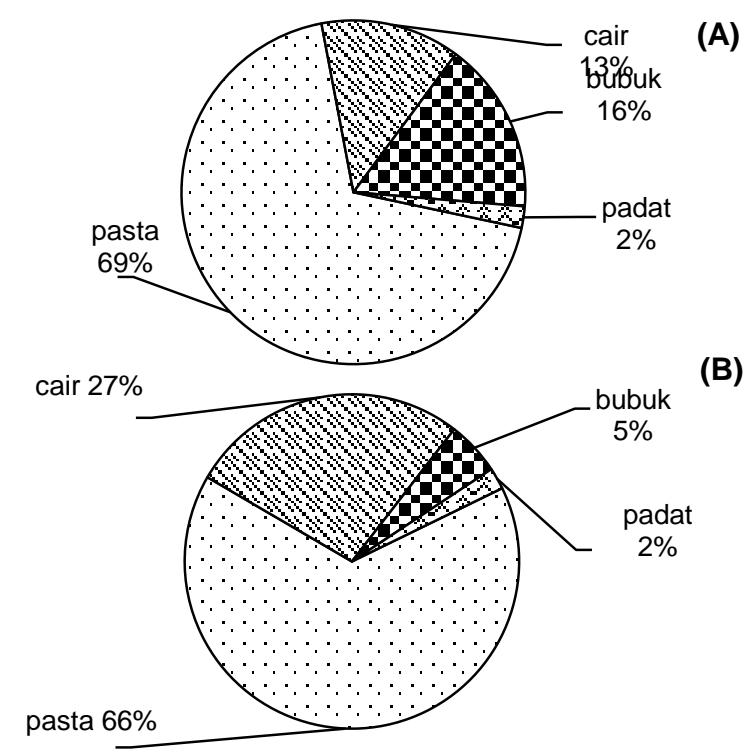

Gambar 2. (A) Profil bentuk fisik sediaan BTP campuran yang terdaftar di BPOM ( $\mathrm{N}=632)$, (B) Profil bentuk fisik sediaan BTP campuran hasil survei $(\mathrm{N}=86)$

\section{Evaluasi kesesuaian antara label edar BTP} campuran dengan peraturan

Tingkat pemenuhan unsur label (Gambar 3) yang paling rendah adalah nama produk, karena banyak yang tidak mencantumkan tulisan BTP campuran sesuai syarat BPOM (2016a). Unsur label takaran penggunaan tingkat pemenuhannya hanya $85 \%$ padahal ini menjadi acuan penggunaan BTP campuran. Tingkat pemenuhan nomor ijin edar sudah di atas $90 \%$, dari 86 sampel hanya 4 sampel yang tidak mencantumkan nomor ijin edar, 1 produk dalam negeri dan 3 produk impor. Unsur label komposisi tingkat pemenuhannya masih $85 \%$, kesalahan penulisan komposisi terletak pada penulisan pewarna, menurut BPOM (2017) pewarna dalam komposisi ditulis golongan, jenis BTP, dan nomor CI (misal pewarna kuning FCF CI. No. 15985) sedangkan yang tertulis pada komposisi hanya golongannya saja yaitu pewarna.
Unsur label waktu kadaluarsa tingkat pemenuhannya sudah $100 \%$, dalam Pratiwi (2018) ditemukan hal yang sama yaitu tingkat pemenuhan kriteria rata-rata unsur label untuk waktu kadaluarsa adalah $100 \%$. Label edar BTP campuran didapat dari 2 supermarket, 1 pasar, dan 6 toko bahan kue di DKI Jakarta. Hasil survei terdapat 4 toko bahan kue yang melakukan repacking BTP campuran perisa dan pewarna dan BTP campuran pewarna ke dalam kemasan plastik yang hanya diberi keterangan merk dan nama jenis untuk waktu kadaluarsa, takaran penggunaan sama sekali tidak dicantumkan. Kegiatan repacking BTP sama dengan kegiatan produksi BTP dimana BTP yang diproduksi dan diedarkan harus mempunyai ijin edar dari pihak terkait (Kemenkes 2012).

\section{Evaluasi kesesuaian penggunaan BTP campuran oleh IRTP}

Sebanyak 3509 IRTP terdaftar di DKI Jakarta, namun hasil cleaning data ternyata jumlah IRTP terdaftar adalah 1397, hal ini disebabkan IRTP yang memproduksi lebih dari satu jenis produk dihitung lebih dari satu kali. Berdasarkan produk, IRTP dikelompokkan ke dalam beberapa kelompok dalam PerKa BPOM nomor HK.03.1.23.04.12.2205 tahun 2012 (Gambar 4).

BTP campuran perisa dan pewarna (78\%) dan BTP campuran pewarna (17\%) adalah BTP campuran yang paling banyak terdaftar di BPOM (2012-2017), menurut Sjahwil et al. (2014) BTP perisa banyak digunakan pada produk bakeri, minuman, dan kembang gula. Menurut Cahyadi (2008) pewarna berbentuk bubuk banyak digunakan untuk mewarnai minuman ringan, pewarna bentuk pasta digunakan pada roti, kue, kembang gula, dan berbentuk cair untuk produk-produk susu.

Identifikasi IRTP yang kemungkinan menggunakan BTP campuran yaitu IRTP yang memproduksi bakeri, minuman dan kembang gula yaitu sebanyak $25 \%$ (343/1397) IRTP (Gambar 5) untuk produk susu tidak dimasukkan karena produk tersebut tidak dapat didaftarkan melalui IRTP.

Tabel 5. BTP Sekunder pada BTP campuran pengemulsi

\begin{tabular}{|c|c|c|c|c|}
\hline \multirow[t]{2}{*}{ BTP Sekunder } & $\begin{array}{l}\text { BTP.C Pengemulsi } \\
\text { (Rata-rata g/kg) }\end{array}$ & $\begin{array}{l}\text { BTP.C Pengemulsi dan } \\
\text { Perlakuan Tepung } \\
\text { (Rata-rata g/kg) }\end{array}$ & $\begin{array}{c}\text { BTP.C Pengemulsi } \\
\text { dan Pewarna } \\
\text { (Rata-rata g/kg) }\end{array}$ & \multirow[t]{2}{*}{$\begin{array}{c}\text { Batas Maksimum Bahan Pembawa (Carier) } \\
\text { dalam BTP }(\mathbf{g} / \mathbf{k g})^{\star}\end{array}$} \\
\hline & $\mathrm{N}=5$ & $\mathrm{~N}=2$ & $\mathrm{~N}=2$ & \\
\hline \multicolumn{5}{|l|}{ Pemanis } \\
\hline $\begin{array}{l}\text { Sorbitol } \\
\text { Pembawa }\end{array}$ & 229 & & 130 & CPPB \\
\hline $\begin{array}{l}\text { Propilen glikol } \\
\text { Pewarna }\end{array}$ & 80 & & 216 & 1 pada produk pangan akhir (sebagai carry over) \\
\hline Tartrazin & 0.004 & & & \\
\hline Kuning FCF & 5 & & & \\
\hline Pengatur Keasaman & & & & \\
\hline Asam asetat & 10 & & & \\
\hline Kalsium asetat & 5 & & & CPPB \\
\hline Antikempal & & & & \\
\hline Kalsium karbonat & & 150 & & CPPB \\
\hline Antioksidan & & & & \\
\hline Tokoferol & & 0.5 & & \\
\hline $\begin{array}{l}\text { Asam askorbat } \\
\text { Perisa }\end{array}$ & & 30 & & \\
\hline Etil vanilin & & & 1.3 & \\
\hline
\end{tabular}




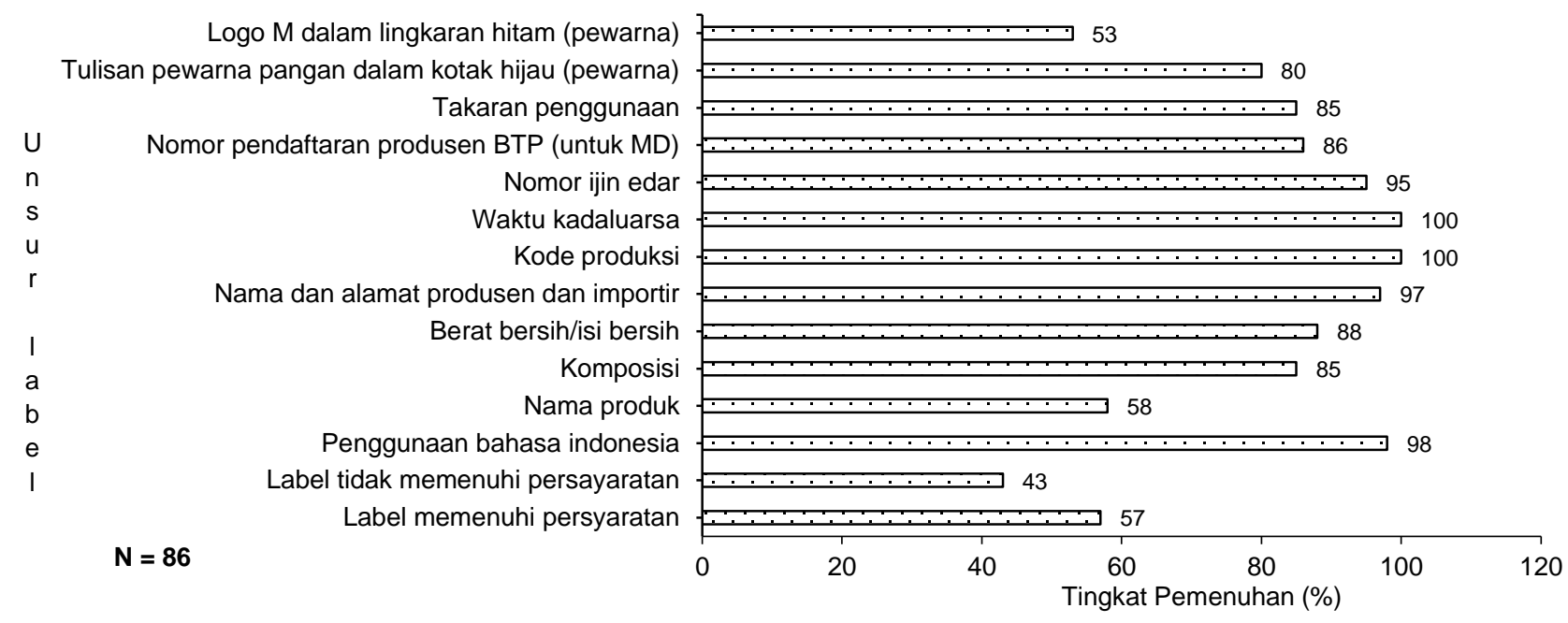

Gambar 3. Tingkat pemenuhan keterangan minimum label BTP campuran dan label yang memenuhi persyaratan

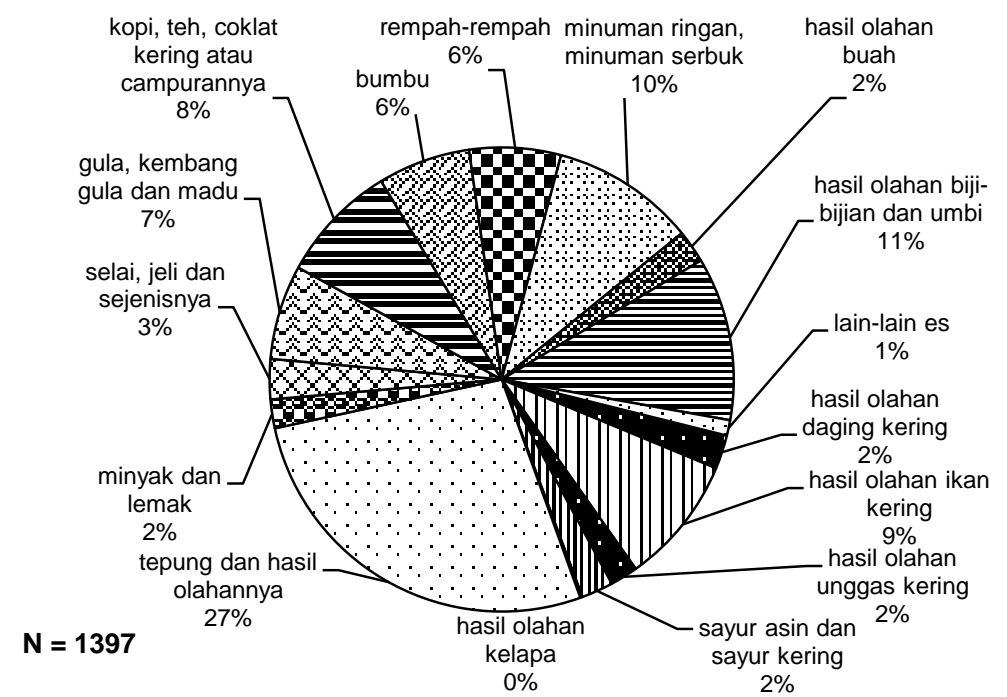

Gambar 4. Profil IRTP terdaftar di DKI Jakarta berdasarkan produk yang dihasilkan pada tahun 2017

Rumus Slovin digunakan untuk menentukan jumlah IRTP yang akan diwawancarai, dari hasil perhitungan diperoleh bahwa jumlah IRTP yang akan diwawancarai adalah sebanyak 77 . Kendala yang dihadapi ketika survei adalah sangat sedikitnya IRTP yang bersedia diwawancarai yaitu hanya sebanyak 18 IRTP yang bersedia untuk diwawancarai, dari 18 IRTP tersebut 7 IRTP menggunakan BTP campuran yaitu yang memproduksi roti manis, cake, bolu, minuman lidah buaya, dan manisan kolang kaling.

Sebanyak 11 IRTP tidak menggunakan BTP campuran yaitu yang memproduksi kue kering (nastar, kukis, kastangel), bir pletok, minuman rasa madu, roti tawar, jus buah, dan minuman kunyit asem, minuman jelly, susu kedelai, minuman instan jasmin tea. Sebanyak 16 BTP campuran digunakan oleh IRTP, kemudian kadar masing masing BTP campuran yang digunakan oleh IRTP tersebut di evaluasi kesesuaiannya dengan peraturan yaitu batas maksimum penggunaan BTP campuran yang ditetapkan oleh BPOM, profil penggunaan BTP campuran oleh IRTP dapat dilihat pada Tabel 5. Berdasarkan hasil survei terhadap 18 IRTP terdapat 7 IRTP yang menggunakan BTP campuran. BTP campuran yang digunakan adalah sebanyak 16 jenis, dari 16 jenis tersebut terdapat 4 BTP campuran yang digunakan melebihi batas maksimum penggunaan yang ditetapkan oleh BPOM, yaitu BTP campuran perisa coklat dan pewarna pada bolu marmer, BTP campuran perisa pandan dan pewarna pada bolu, BTP campuran perisa coklat dan pewarna pada bolu serta BTP campuran perisa pandan dan pewarna pada produk roti manis.

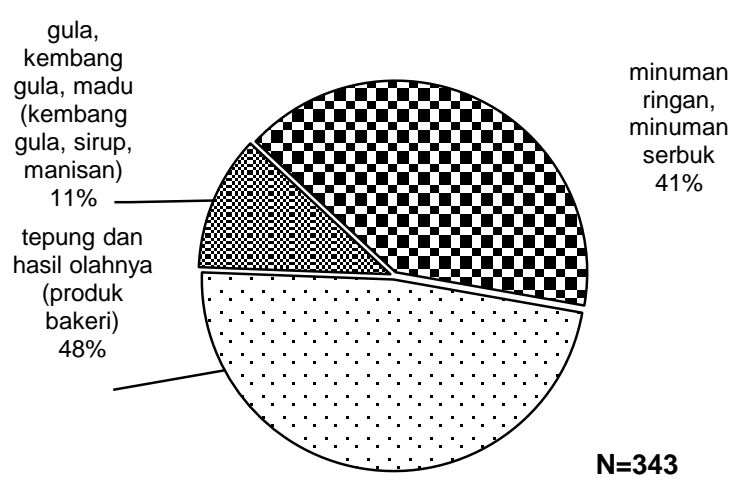

Gambar 5. Profil IRTP berdasarkan produk yang dihasilkan diduga menggunakan BTP campuran 


\section{KESIMPULAN}

BTP campuran yang terdaftar di BPOM 2012-2017 didominasi oleh BTP campuran perisa dan pewarna sebesar $78 \%$. Komposisi dari BTP campuran yang terdaftar dibagi menjadi 3 bagian yaitu BTP utama yang mempunyai fungsi teknologi pada produk pangan akhir, BTP sekunder yang mempunyai fungsi teknologi pada sediaan BTP campuran dan zat tambahan lainnya yang menentukan bentuk sediaan dari BTP campuran. Tingkat pemenuhan label edar yang sesuai dengan peraturan adalah sebesar $57 \%$ hal ini untuk menjadi perhatian regulator terkait untuk dilakukan evaluasi post market. Berdasarkan hasil survei terhadap 18 IRTP terdapat 7 IRTP yang menggunakan BTP campuran dengan BTP campuran yang digunakan adalah sebanyak 16 jenis dari 16 jenis tersebut terdapat 4 BTP campuran yang digunakan melebihi batas maksimum penggunaan yang ditetapkan oleh BPOM.

\section{DAFTAR PUSTAKA}

Blank I, Pascual EC, Devaud S, Fay LB. 2002. Degradation of the coffee flavour compound furfuryl mercaptan in model fenton-type reaction system. J Agr Food Chem 50(8): 2356-64. DOI: 10.1021/jf01 $1329 \mathrm{~m}$.

[BPOM] Badan Pengawas Obat dan Makanan. 2012. Peraturan Kepala Badan Pengawas Obat dan Makanan Republik Indonesia Nomor HK.03.1. 23.04.12.2205 Tahun 2012 Tentang Pedoman Pemberian Sertifikat Produksi Pangan Industri Rumah Tangga. Jakarta: BPOM.

[BPOM] Badan Pengawas Obat dan Makanan. 2013. Peraturan Kepala Badan Pengawas Obat dan Makanan Republik Indonesia Nomor 6 Tahun 2013 Tentang Batas Maksimum Penggunaan Bahan Tambahan Pangan Pembawa. Jakarta: BPOM.

[BPOM] Badan Pengawas Obat dan Makanan. 2016a. Peraturan Kepala Badan Pengawas Obat dan Makanan Republik Indonesia Nomor 8 Tahun 2016 Tentang Persyaratan Bahan Tambahan Pangan Campuran. Jakarta: BPOM.

[BPOM] Badan Pengawas Obat dan Makanan. 2016b. Peraturan Kepala Badan Pengawas Obat dan Makanan Republik Indonesia Nomor 22 Tahun 2016 Tentang Persyaratan Penggunaan Bahan Tambahan Pangan Perisa. Jakarta: BPOM.
[BPOM] Badan Pengawas Obat dan Makanan. 2017. Peraturan Kepala Badan Pengawas Obat dan Makanan Republik Indonesia Nomor 27 Tahun 2017 Tentang Pendaftaran Pangan Olahan. Jakarta: BPOM.

Cahyadi W. 2008. Analisis dan Aspek Kesehatan Bahan Tambahan Pangan. PT Bumi Aksara, Jakarta.

Dewayani W, Muhamad H, Kadir A, Nappu MB. 2002. Pengaruh bahan penstabil terhadap mutu sari buah markisa. J Hortikultura 12(2): 110-117.

European Commission. 2011. Commission regulation (Eu) No 1130/2011 on amending annex III to regulation (EC) No 1333/2008 of the European Parliament and of the council on food additive, food enzyme, food flavourings and nutrients. J European Union 54(1): 178-204. DOI: 10.3000/19770677.L_ 2011.295.eng.

Hausch B, Lorjaroenphon Y, Cadwallader KR. 2014. Flavor chemistry of lemon-lime carbonated beverages. J Agri Food Chem 63(1): 112-119. DOI: 10.1021/jf504852z.

[Kemenkes] Kementerian Kesehatan. 2012. Peraturan Menteri Kesehatan Nomor 33 Tahun 2012 Tentang Bahan Tambahan Pangan. Jakarta: Kemenkes.

Kumar R, Sharma PK, Mishra PS. 2012. A review on the vanilin derivatives showing various biological activities. J Pharmtech Res 4(1): 266-279.

Lee J, Chambers DH, Chambers E, Adhikari K, Yoon Y. 2013. Volatile aroma compounds in various brewed green teas. J Molecules 18(1): 10024-10041. DOI: 10.3390/molecules.

Nasution R. 2003. Teknik Sampling. http://www.library. usu.ac.id $>$ fkm $>$ fkm-rozaini.

Pratiwi RP. 2018. Studi Bahan Tambahan Pangan dan Kesesuaian Label Kemasan pada Makanan Ringan Ekstrudat di Bogor. [Skripsi]. Bogor: Institut Pertanian Bogor.

Rahayu WP. 2011. Keamanan Pangan Kepedulian Kita Bersama. PT Penerbit IPB Press, Bogor.

Sevilla CD. 2007. Research Methods. Rex Printing Company, Quezon City.

Sjahwil LN, Andarwulan N, Hariyadi P. 2014. Tren flavour produk pangan di Indonesia, Malaysia, Filipina, dan Thailand. J Mutu Pangan 1(1): 9-18.

Zhu G, Xiao Z. 2015. Study on creation of an indocalamus leaf flavour. J Food Sci Technol 35(4): 647-651. DOI: 10.1590/1678-457X.6770.

JMP-05-18-18-Naskah diterima untuk ditelaah pada 27 Mei 2018. Revis makalah disetujui untuk dipublikasi pada 09 Maret 2019. Versi Online: http://journal.ipb.ac.id/index.php/jmpi 